\author{
Anastasiia Kuznietsova \\ $\mathrm{PhD}$ in Linguistics \\ Université Sorbonne Paris Cité \\ ORCID ID 0000-0002-7256-8215 \\ anastasiia.kuznietsova@gmail.com
}

\title{
GENDER DIFFERENCE IN LANGUAGE USE AND LANGUAGE ATTITUDES IN ONLINE FACEBOOK POSTS OF UKRAINIAN MIGRANTS IN GERMANY
}

\begin{abstract}
This article studies the gender difference of language use and language attitudes of Ukrainian communities in Germany in online social media. Since 2014, the conflict in the East of Ukraine has led to a remarkably intense flow of Ukrainian migrants to Western Europe giving rise to longstanding issues of identity formation, language use and attitudes both within Ukraine and inside Ukrainian diaspora communities. This article will examine Ukrainian diaspora in Germany on the subject of language ideologies, language use and attitudes by analyzing its linguistic online activity. To do so, our analysis will draw on a range of interdisciplinary methodologies, including studies of linguistic identity positioning, gender in migration, imagined migrant communities, and studies of discursive constructions of nationhood, which explore language indexing in relation to national identity. Social media data were collected from Facebook groups in Germany basing on follower numbers, the variety of language use, frequency of posts, and the variety of their social, cultural or political focusIt is noted that language use by members of the three studied Facebook groups in no way represents the positioning of all Ukrainian immigrants in that country. In addition, the lack of access to the migrants' offline multimodal and dialogic language interactions posed limitations on this study. It was concluded that as opposed to men, Ukrainian migrant women may likely to develop less-Ukrainian oriented identities with less attention paid to the Ukrainian language. Therefore, while national mythologies view women as responsible for upholding Ukrainian language and traditions, women themselves, as opposed to Ukrainian men, tend to use internationally established languages as a marker for their social advancement. Thus, in the future perspective, language use and attitudes, as well as immigrants' identity research would benefit from additional studies that examine more diverse groups of immigrants and by adding additional methods.
\end{abstract}

Keywords: gender; language use; language attitude; linguistic identity; diaspora.

\section{INTRODUCTION}

This paper investigates gender differences in language use and language attitudes of Ukrainian migrants in Germany using data from Facebook posts. By means of a qualitative approach, Ukrainian immigrants' online activity analyzed to show whether Ukrainian national gender norms are challenged or reinforced by distance from the homeland and weather these factors influence on language use and attitudes in a transnational context. The choice of a qualitative research paradigm for this study allows for more in-depth, nuanced exploration of language use, language attitudes and is in keeping with other research in the field of migration studies ${ }^{1}$ and the role of gender in migration. ${ }^{2}$

1 Guardado, M. (2012). Toward a critical multilingualism in Canadian classrooms: Making local inroads into a cosmopolitan identity. TESL Canada Journal, 30 (1), 151-165; Kramsch, C. (2009). The multilingual self. Oxford, United Kingdom: Oxford University Press; Kramsch, C., \& Candlin, C. (2003). Identity, role and voice in cross-cultural (mis)communication. In J. House, G. Kasper, \& S. Ross (Eds.), Misunderstanding in Social Life (pp. 129-153). London, United Kingdom: Pearson Education; Norton, B. (2013). Identity and language learning: Extending the conversation. Bristol, United Kingdom: Channel View Publications/ Multilingual Matters.

${ }^{2}$ Gewinner, I. (2020). Gender Norms, Sexuality and Post-Socialist Identity: Does Migration Matter? Sexuality \& Culture, 24, pp. 465-484; Curro, K. (2012). 'National Gender Norms and Transnational Identities: Migration Experiences of Georgian Women in London,' SLOVO, 24(2), 114-131.

(C) Anastasiia Kuznietsova. 2022. Published by Igor Sikorsky Kyiv Polytechnic Institute. This is an Open Access article distributed under the terms of the licence CC BY 4.0 
Until recently, relatively little explicit attention has been paid to gender differences in patterns of language use, attitudes, language maintenance and shift. Furthermore, according to Clifford, diasporic experiences are always gendered, but still the gender dimension was largely ignored in the sociolinguistic research. There is a tendency for theoretical accounts of diasporas and diaspora cultures to hide this fact, to talk of travel and displacement in unmarked ways, thus normalizing male experiences. ${ }^{3}$

The choice of Facebook as a main source of the data is foregrounded by several reasons. Firstly, the media play a crucial role in language use and construction of identities in contemporary societies, because of the intensity of most people's participation in various types of media discourse (Kulik, 2018) ${ }^{4}$. Secondly, a number of studies have proven media contributions to the pre-eminence of national and linguistic identity and media representations of various ethno cultural and sociodemographic groups (van Dijk, 1989; Morley, 2004; Gauntlett, 2008). ${ }^{5}$ According to theses scientific works, language is an important aspect of identity which can be discussed in specific groups or pages and performed in profiles or updates.

The Ukrainian migrant community is particularly interesting object for study because of the complexity of relations between language use and national identification in Ukraine, especially after the awake of the Maidan Revolution in 2014. The war in Eastern Ukraine and the threat to its territorial integrity caused the spurt of patriotic language ideologies in Ukraine which tied national identity to the speaking of a particular language. However, in the 2017 census many who identified themselves as "Ukrainians" by nationality declared Russian as their primary language of quotidian communication. ${ }^{6}$ How these controversies play out among migrants in gender perspective we don't yet know.

According to Matthias Lücke and David Saha (2019) and Eurostat statistics the number of residences permits for Ukrainians doubled during the last decade and was around 1.2 million in 2018. Currently, after Italy, one of the biggest numbers of Ukrainian migrants to EU reside in Germany ${ }^{7}$. These migrants could become more numerous in the future taking into account ongoing tensions on the East of Ukraine. Thus, post-2014 Ukrainian migrants in Germany provide a rich case for studying as an inherently bilingual community and vulnerable migrant group from the country in the state of conflict.

\section{METHODS}

Social media data were collected from Facebook groups in Germany basing on follower numbers, the variety of language use, frequency of posts, and the variety of their social, cultural or political focus. ${ }^{8}$ Building on previous social media data-based research into online language use, attitudes and multilingualism, ${ }^{9}$ the studied content in this article include verbal and/or visual texts (announcements, inquiries, articles) and is supplemented by analysis of the accompanying "discussions", comprising comments. The analysis of the data is informed by Harré and van

${ }^{3}$ Clifford, J. (1994). Further Inflections: Toward Ethnographies of the Future, Cultural Anthropology, 9(3), 302-338.

${ }^{4}$ Kulyk, V. (2018). Between the "Self" and the "Other": Representations of Ukraine's Russian-speakers in Social Media Discourse. East/West: Journal of Ukrainian Studies, 5(2).

5 van Djik, Teun, A (1989). Mediating Racism. The Role of the Media in the Reproduction of Racism. Language, Power and Ideology. Studies in Political Discourse, edited by Ruth Wodak, John Benjamins Publishing. pp. 199-226; Morley, D. (2004). Broadcasting and the Construction of the National Family. In R. C. Allen and A. Hill (Eds.), The Television Studies Reader (pp. 418-41). Routledge; Gauntlett, D. (2008). Media, Gender and Identity: An Introduction. Routledge.

6 Masenko, L. (2018). Movnyi konflikt v Ukrayini. Shlyakhy rozvyazannya [Language conflict in Ukraine. Ways for resolution]. Ukraïnska mova [Ukrainian language], 2, p. 20.

${ }^{7}$ Lücke, M., Saha, D. (2019). Labour migration from Ukraine: Changing destinations, growing macroeconomic impact. German Advisory Group, Policy Studies Series, p. 3.

${ }^{8}$ Dailey-O'Cain, J. (2017). Trans-National English in Social Media Communities. Palgrave Macmillan. Series on Language and Globalization, p. 55.

9 Androutsopoulos, J. (2006). Multilingualism, Diaspora, and the Internet: Codes and Identities on German-Based Diaspora Websites. Journal of Sociolinguistics, 10(4), 520-547. 
Langenhove's (1991) $)^{10}$ understandings of linguistic identity positioning, Norton and Toohey's $(2011)^{11}$ concept of imagined communities, and Pavlenko's $(2007)^{12}$ recommendations for data examination in applied linguistics. This study responds to an identified gap in gender research around migrants' linguistic behavior on Facebook during their sojourn in the host country.

\subsection{Research Questions}

Our main research questions are as follows:

- How do Ukrainian migrant groups residing in Germany use language(s) via social media platforms and what are their language attitudes (e. g., towards Ukrainian, Russian, or the language of the host country)?

- What is the role of gender in these processes?

There is also an additional research objective to guide us upon our discoveries such as to study sociocultural positioning and identities of Ukrainian migrants. In this way the paper explores the modern Ukrainian transnational identities as constructed by different language ideologies among Ukrainian migrants who came to the Germany to study and work.

\section{RESULTS AND DISCUSSION}

As mentioned above, one of this article central concern is the influence of gender as a social factor which impacts on linguistic behavior. Gender is an important differentiating factor, as it may affect ideas about roles in society and about the importance of language as well as migrants' responses to the current conflict on the East of their native country.

According to previous studies of post-2014 Ukrainian migrant families, there is a tendency to pass Ukrainian, as a heritage language to female descendants (Seals, 2019). ${ }^{13}$ An older study has also shown clear differences in linguistic behavior between men and women in Ukrainian society. Thus, according to Bilaniuk (2003) meanwhile, mythologies of idealized womanhood depict women as responsible for upholding national language and traditions, women's themselves tend to show relatively more support than do Ukrainian men for languages of world status, such as English. ${ }^{14}$

\subsection{Ukrainian Facebook Groups in Germany}

For our analysis we have chosen three largest Ukrainian Facebook groups in Germany. The first is Ukrainians in Germany ('Українці в Німеччині') counting 45,400 followers, which was found in 2017 and operates on controlled membership granted by administrators based on Ukrainian origin or citizenship. The second is the group Ukrainians in Berlin ('Українці у Берліні') found in 2018 with 6700 members. The third is Ukrainians in Munich ('Українці у Мюнхені'), which was found in 2011 and currently counts 2700 members. All studied groups have been running as a platform for discussions considering work \& money, health, education, important places in Germany, communication \& travel, government \& local authority information and the news from the homeland.

We analyzed the posts of each Facebook group within the period between $20^{\text {th }}$ to $24^{\text {th }}$ of April 2021 and between $20^{\text {th }}$ of September to $24^{\text {th }}$ of October 2021 to see which is a primary

\footnotetext{
${ }^{10}$ Harré, R., \& van Langenhove, L. (1991). Varieties of positioning. Journal for the Theory of Social Behaviour, 21(4), 393-407.

${ }^{11}$ Norton, B., \& Toohey, K. (2011). Identity, language learning, and social change. Language Teaching, 44(4), 412446.

12 Pavlenko, A. (2007). Autobiographic narratives as data in applied linguistics. Applied Linguistics, 28(2), 163-188.

${ }^{13}$ Seals, C. (2019). Choosing a mother tongue: The politics of language and identity in Ukraine. Bristol: Multilingual Matters, p.116.

${ }^{14}$ Bilaniuk, L. (2003). Gender, language attitudes, and language status in Ukraine. Language in Society, 32(1), 47-78.
} 
language of men and women's communication and whether multiple languages were used. Due to privacy issues, we were unable to check the identity of the participants to see whether they're native Ukrainian speakers or are just of Ukrainian heritage. The gender factor studied in this article may also depend on intersecting aspects, such as class, regional background, family status, age and education. However, theses variables were not taken into consideration as we could only go off the names provided by the members of the group.

For additional information the group of Ukrainian Women in Germany was taken. However, in order to keep the balance in statistics we did not take into account the number of posts of this group, as it is opened for membership only for female users. However, the design of this group page is particularly interesting for the present research as it demonstrates clearly gendered content of its front page with traditional Ukrainian women-dolls drown on the background with Ukrainian flag.

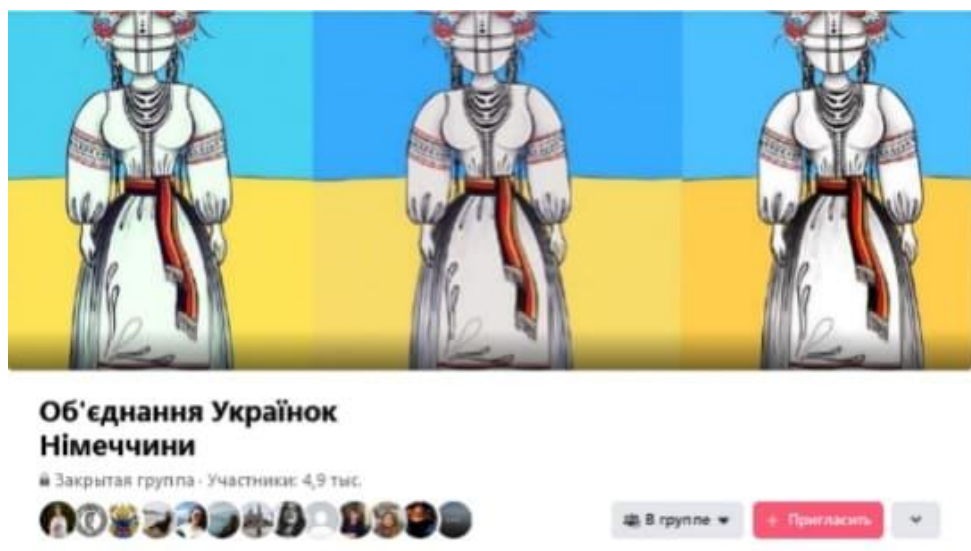

Fg. 1. Ukrainian Women in Germany ('Об’ сднання Українок Німеччини') Facebook page

Similarly, to the previous Facebook group - Ukrainians in Munich also shows gendered visual content on its front page - the head of Ukrainian woman decorated by flower crown, which is a traditional Ukrainian decoration for women.

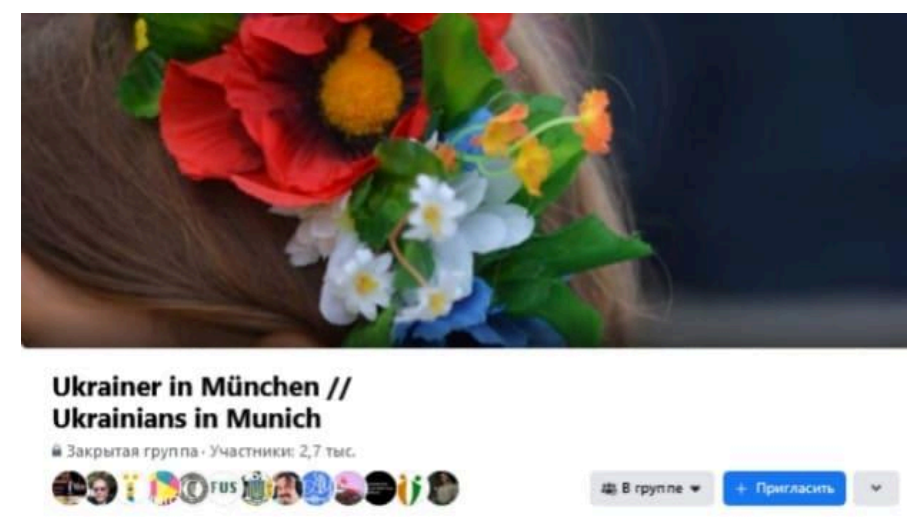

Fg. 2. Ukrainians in Munich Facebook page

Both of abovementioned groups demonstrate the patriotic vision of Ukrainian women as a guardians of Ukrainian traditions, and, apparently aim to preserve the national identity and by implication raise awareness of Ukrainian state language use to its participants.

Language use. Language use in this study refers to both the frequency and complexity of male and female migrants' use of Ukrainian and Russian (rarer German and English). Throughout the studied period I found posts by female users in Ukrainian $(n=49)$, Russian $(n=10)$, German $(\mathrm{n}=3)$, English $(\mathrm{n}=2)$ or such codeswitching as both Russian and German $(\mathrm{n}=2)$, Ukrainian and German $(n=2)$, Ukrainian and English $(n=1)$. The distribution of language use by male users is as 
follows: Ukrainian $(\mathrm{n}=35)$, Russian $(\mathrm{n}=7)$, German $(\mathrm{n}=0)$, or both Ukrainian and German $(n=2)$.

Language attitude. Language attitude refers to the posts that users made about language during the studied period. During the survey, I observed how users express their opinion on usage of different languages. It also includes the language choice, which often depends on the content of the post. Thus, for instance, Ukrainian was used for marketing purposes in Germany, often with some creative and patriotic aim, and German - to mark the belonging to the bi-/multilingual migrant community and integration into the host society.

As the study shown, for the majority of posts and discussions, the first language of choice is Ukrainian (84 out of the 113 posts in all groups). This may be illustrated by the following example:

(Af) ${ }^{15}[\mathbf{U}]{ }^{16}$ Good day to all. Who applied for a family reunion visa last month? Have you been invited to additional interview? Or asked to bring supplementary documents?...

$(\mathbf{B m})[\mathbf{U}]$ If there would be a nessecity in additional documents, they would inform you beforehand. (Cf)[R] I was asked to give a certificate of divorce. If this is your first marriage, then its easier for you.

(Af)[U] Thank you. Understood.

Nevertheless, the frequency of any language use differs significantly by gender. Thus, female users showed the evidence of more frequent use of Russian. As an example, illustrating this language choice as well as the language attitudes of other users regarding this publication may be found on the page of Ukrainians in Munich:

(Af)[R] Good day! Do you want to improve your German? I offer grammar lessons of any level. I conduct lessons on such topics as economics, art and business German. All classes are held online.

$(\mathrm{Bm})[\mathrm{R}]$ Price?

(Cf)[R] Price?

(Df)[U] Price?

(Em)[U] You better improve your Ukrainian.

From the comments of the male user E we clearly see the critics towards this post which can be interpreted both as the negative attitude for the author's Russian language choice and/or the fact of proposing to study German language. It is worth mentioning that user E does not criticize the Russian speaking comment of male user B and his critical comment was supported by two likes from other users of masculine gender.

Another example of the similar reaction was found in the group Ukrainians in Germany with a request of Ukrainian woman to find a Russian speaking doctor. This post got the similar negative reaction from male users $\mathrm{F}, \mathrm{G}$ and $\mathrm{H}$.

(Af)[R] Please help to find a Russian-speaking gynecologist in Leipzig who knows

(Bf)[U] I know there is one in Halle

(Cf)[R] In the center near Höfe am Brühl there is Frau Metzler

(Df)[U] There is a group of Ukrainians in Leipzig

(Em)[U] Make the Germans learn Russian! What a disgrace!

(Fm)[U] You must go into the community Russians of Germany

\footnotetext{
${ }^{15}$ In examples, personal names have been changed to ensure anonymity of the participants.

16 All examples are presented in English, as this is the practice followed by EWJUS. The original language of interaction is indicated as follows: [U] - Ukrainian, [R] - Russian, [G] - German. The gender of the user is marked by [f] - female, and [m] - male. All translations are mine.
} 
(Gm)[U] You need to go into the community of Russians

(Hm) [U] Learn German, ***.

From the comments of this post we may also see that female users show neutral language attitude and use Ukrainian or Russian in order to help the author with requested advice. On the other hand, male speakers E, F and G display their dissatisfaction with the fact that the author is willing to have a Russian speaking doctor in non-Russian speaking country and perhaps by the fact that the request is posted in Russian. The last comment made by male user $\mathrm{H}$ shows the evidence of extremely hostile attitude to the language choice and/or post content of the author, as it contains sexist insult which I masked under asterisks. Thus, by these emotional comments male users demonstrate their loyalty and belonging to Ukrainian speaking immigrant community and nonacceptance for its outsiders. According to gathered data, women, compared to men, tend to demonstrate either neutral attitude or more loyalty to Russian (as shown above) as well as to other international languages such as German and English. Thus, we found 3 posts written completely in German or English (2 posts) by female users. Women also more actively demonstrate various codeswitching such as Russian / German, Ukrainian / German, and Ukrainian / English. While there were isolated examples found with occasional Ukrainian-German code switching created by male users as shown in the example below:

(Am)[U] Prompt a proven company for employment on a Polish visa!

(Bm)[U] I also want to find such a company

(Cf)[R] There are no such companies, you cannot work legally in Germany on a Polish visa.

You can only work in Poland. If you do not believe me, then write this question in the group

Laws of Germany, where you will get answer from lawyers

(Em)[U] Zoll has an exact information:))) ...

(Fm)[G] Zoll

(Gm)[G] Bundespolizei und Zollamt

In this sample, speaker A begins his appeal in Ukrainian. Female speaker $\mathrm{C}$ communicates in Russian, male speaker E code-switch between Ukrainian and German, and finally male speakers $\mathrm{F}$ and $\mathrm{G}$ respond in German. It is worth mentionning that ZOLL is an abbreviation for the German Bundeszollverwaltung (Federal Customs Service) that in this context can only be understood by a German-Ukrainian bilingual. In this way male users E, F and $\mathrm{G}$ by using it, position themselves as members of immigrant multilingual community, while calling on all members of this imagined community to recognize the joke and laugh along with them. Meanwhile, within the studied period, men did not publish any post entirely in German or English (except comments under publications), as opposed to women. In the following post by using German for entire publication, woman-author positions herself on Facebook as well integrated member of the host society confident enough to post information in German, without any additional explanation in Ukrainian or Russian:

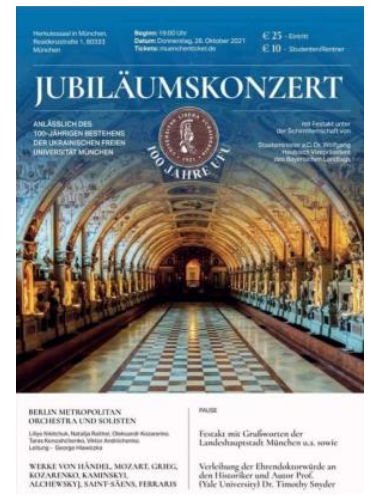

Fg. 3. Ukrainians in Berlin - post in German to advertise the cultural event 
It should be emphasized that the majority of the posts in the studied groups were purely written in Ukrainian (both by men and women) followed by Ukrainian and in the lesser extent by Russian comments. We presume that a possible reason for the high proportion of Ukrainian language choice on these Facebook pages may be foregrounded by active encouraging to preserve the Ukrainian national identity as we may conclude from the names of these groups and especially their patriotic graphic design. This is especially applicable to the group of Ukrainian Women in Germany, where Ukrainian is used for every single publication.

Besides that, the survey shows, that gender differences are visible not only in language use (mostly Ukrainian or Russian), but also in the content of publications and the language choice depening on this content. Thus, the text and visual content of the majority of the observed publications reflects traditional gender roles distribution among the members of the studied migrant community. Therefore, men use to post information connected to activities traditionally attributed to men, such as job announcements, technical questions (e.g., gadgets, personal computer upgrading) or transportation services:

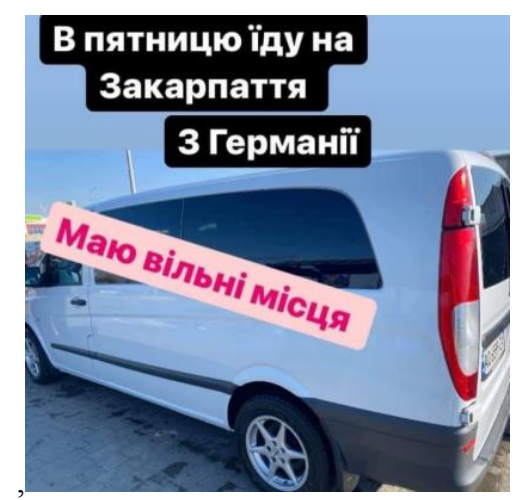

Fg. 4. Ukrainians in Berlin - post in Ukrainian to advertise the transportation services between Germany and Western Ukraine

At the same time the posts of religious character or associated with Ukrainian traditions, traditional clothes, and beauty procedures are more often written by women and use only Ukrainian language for such kind of content:

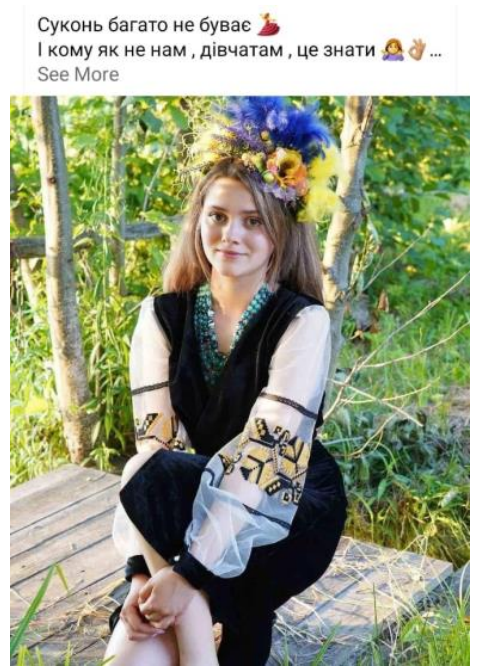

Fg. 5. Ukrainians in Berlin - post in Ukrainian to advertise Ukrainian traditional dresses 
The possible reason for that is that national traditions have been very strong in Ukrainian history, (e. g., language, family traditions, and the church) which played a role in regulating gender norms and behavior and as a powerful element of resistance against foreign invaders and oppressors (be they Muslim neighbors, the Russian Empire or the Soviet regime). As Dragadze points out in her ethnography study, "all people who are female are the potential source and bearers of life, and so it is thought that all essential female characteristics derive from that" ${ }^{17}$ Furthermore, Ukraine itself, as a nation, culture, and ethnic entity is invariably symbolized by a woman. This country is referred to as Nen'ka, "Mommy". The Ukrainian language is Kalynova, "Guelder rose", which is the ancient female marriage symbol. The capital of Ukraine, Kyiv, is Mati mist' rus'kih, "Mother of the towns of Rus". Women are expected to have certain attributes, such as constancy, stability, and reliability (qualities considered to be weaker in men), as well as bashfulness, flexibility, and pragmatism. ${ }^{18}$ This does not mean that women are regarded as lower beings per se. On the contrary, womanhood is considered as a fundamental part in the historical and cultural imagery of the nation. However, women are valued as "Ukrainians" only to the extent to which they comply with roles considered 'natural' to them and their native culture; womanhood and motherhood are regarded as two inseparable categories. ${ }^{19}$ At the same time the typical expectations from the men in the Ukrainian society is activity, intelligence, rationality, independence, strength (mental and physical), aggressiveness, restraint of emotions, being full of ambition and prone to risk, ${ }^{20}$ which is also reflected in the linguistic behavior, language attitudes and the visual-textual content of the studied online publications.

\section{CONCLUSIONS AND SCOPE FOR FURTHER RESEARCH}

Our research was aimed at analyzing the content for Ukrainian migrants' Facebook groups speech on the subject of language use and language attitudes. Our first conclusion is that Ukrainian is used as the primary language of communication, and is central in online interactions, meanwhile German, English and Russian are used to considerably lesser degrees. As shown in this paper, in the context of the Facebook groups under this study, language use and language attitudes are largely inflected by gender. It should be also noted that language use by members of the three studied Facebook groups in no way represents the positioning of all Ukrainian immigrants in that country. In addition, the lack of access to the migrants' offline multimodal and dialogic language interactions posed limitations on this study. Therefore, in the future perspective, language use and attitudes, as well as immigrants' identity research would benefit from additional studies that examine more diverse groups of immigrants and by adding additional methods.

Despite these limitations, we argue that this study sheds light on Ukrainian migrants' language practices as well as their sociocultural identity positioning. It indicates that among online immigrant groups in Germany, women tend to use the posts in Ukrainian language to express their belonging and relation to national tradition, more intensely. This is especially confirmed by patriotic graphic design in the group of Ukrainian Women in Germany where Ukrainian is used in every single publication. It is suggested that several interrelated factors contribute to the tendency for women to maintain this linguistic behavior: firstly, Ukrainian tradition tend to place a high value on the distinctive social and affective functions expressed by the ethnic language. In this way, within the

\footnotetext{
17 Dragadze, T. (1988). Rural Families in Soviet Georgia: A Case Study in Racha Province. London and New York: Routledge. p. 159.

18 Kis, O. (2008). Zhinka v tradytsiyniy ukrayinskiy kulturi [Women in traditional Ukrainian culture]; LundkvistHoundoumadi, M. (2010). Treading on the Fine Line Between Self-Sacrifice and Immorality: Narratives of Emigrated Georgian Women. Transcience Journal, 1, 50-71.

${ }^{19}$ Statistical data showing how these patterns are still strongly rooted within contemporary Ukrainian society can be found in a 2019 UNFPA Ukraine survey (UNFPA Ukraine. (2019). Gender Equality and Response to Domestic Violence in the Private Sector of Ukraine: Call for Action.

20 Timoshchuk, Yu. (2013). Obraz cholovika u masoviy kulturi [Image of man in mass culture]. Hender ta filosofiya. Hender ta kulturolohiya [Gender and philosophy. Gender and culturology], 94-101.
} 
migrant community, women are supposed to adapt their own lives and self-perceptions to roles ascribed to them by what is seen as national tradition. Finally, such linguistic behavior could be the consequence of intensive critics of language use other than Ukrainian (especially Russian) from the side of men, especially towards female users as the study shows. Thus men, being at the same extent productive for publishing Ukrainian speaking content, may, though less frequently, use Russian, scarcely receiving any critical remarks. In contrast to women, they also tend to demonstrate negative language attitudes, especially towards the usage of Russian language by female users.

However, there is a certain ambiguity observed in linguistic online behavior of female users. More often than men, they may use German (sometimes English) language. Findings revealed that women in a greater extent demonstrate their expertise in the foreign languages, and more frequently position themselves as German-Ukrainian bilinguals. In addition, no German or English-speaking post by men was found during the study.

We argue that the less loyalty of men to other languages in online communication shows their stronger attachment to idea that national language is a constitutive part of Ukrainian identity. Thus, the male members of migrant community position themselves as stricter censors of linguistic behavior and to certain extent put on Ukrainian womanhood the major responsibility for upholding the Ukrainian language and traditions. Consequently, performing their purist language policy in Ukrainian migrant online community allows Ukrainian men to have power, which is in line with the social order they know from Ukraine.

In this way we may conclude that, as opposed to men, Ukrainian migrant women may likely to develop less-Ukrainian oriented identities with less attention paid to the Ukrainian language. Therefore, while national mythologies view women as responsible for upholding Ukrainian language and traditions, women themselves, as opposed to Ukrainian men, tend to use internationally established languages as a marker for their social advancement.

Thus, in the future perspective, language use and attitudes, as well as immigrants' identity research would benefit from additional studies that examine more diverse groups of immigrants and by adding additional methods.

\section{REFERENCES}

Androutsopoulos, J. (2006). Multilingualism, diaspora, and the Internet: Codes and identities on German-based diaspora websites. Journal of Sociolinguistics, 10, 520-547.

Bazeley, P. (2013). Qualitative Data Analysis: Practical Strategies. SAGE Publications Ltd.

Coupland, N. (2012). Bilingualism on Display: The Framing of Welsh and English in Welsh Public Spaces. Language in Society, 41, 1-27.

Curro, K. (2012) National Gender Norms and Transnational Identities: Migration Experiences of Georgian Women in London, SLOVO, 24(2), 114-131.

Dailey-O'Cain, J. (2017) Trans-National English in Social Media Communities. Palgrave Macmillan. Series on Language and Globalization.

Danet, B., \& Herring, S. (2007). The Multilingual Internet: Language, Culture, and Communication Online. Oxford University Press.

Gewinner, I. (2020). Gender Norms, Sexuality and Post-Socialist Identity: Does Migration Matter? Sexuality \& Culture, $24,465-484$.

Guardado, M. (2012). Toward a critical multilingualism in Canadian classrooms: Making local inroads into a cosmopolitan identity. TESL Canada Journal, 30(1), 151-165.

Harré, R., \& van Langenhove, L. (1991). Varieties of positioning. Journal for the Theory of Social Behaviour, 21(4), 393-407.

Norton, B., \& Toohey, K. (2011). Identity, language learning, and social change. Language Teaching, 44(4), 412-446. http://doi.org/10.1017/S0261444811000309

Irvine, T., \& Gal, S. (2012). Language Ideology and Linguistic Differentiation. In P. V. Kroskrity, (Ed.), Regimes of Language: Ideologies, Polities and Identities (pp. 35-84). Santa fe \& Oxford.

Kis, O. (2008). Zhinka v tradytsiyniy ukrayinskiy kulturi [Women in traditional Ukrainian culture] Lviv, Instytut narodoznavstva NAN Ukrainy. [in Ukrainian]

Kramsch, C. (2009). The multilingual self. Oxford University Press.

Kramsch, C., \& Candlin, C. (2003). Identity, role and voice in cross-cultural (mis)communication. In J. House, G. Kasper, \& S. Ross (Eds.), Misunderstanding in Social Life (pp. 129-153). London: Pearson Education.

Kulyk, V. (2018) Between the "Self" and the "Other": Representations of Ukraine's Russian-speakers in Social Media 
Discourse. East/West: Journal of Ukrainian Studies, 5(2). 65-88. http://doi.org/10.21226/ewjus419

Kulyk, V. (2016). Language Ideologies in the Era of Facebook: Ukrainian Social Network Discussions within and across Borders. Canadian Institute of Ukrainian Studies Seminars, 11 May, University of Alberta. Lecture.

Lücke, M., \& Saha, D. (2019). Labour migration from Ukraine: Changing destinations, growing macroeconomic impact. German Advisory Group, Policy Studies Series.

Lundkvist-Houndoumadi, M. (2010). Treading on the Fine Line Between Self-Sacrifice and Immorality: Narratives of Emigrated Georgian Women. Transcience Journal, 1, 50-71.

Masenko, L. (2018). Movnyi konflikt v Ukrayini. Shlyakhy rozvyazannya [Language conflict in Ukraine. Ways for resolution]. Ukraïnska mova [Ukrainian language], 2, 20. [in Ukrainian]

Norton, B. (2013). Identity and language learning: Extending the conversation. Bristol: Channel View Publications / Multilingual Matters.

Pavlenko, A. (2007). Autobiographic narratives as data in applied linguistics. Applied Linguistics, 28(2), $163-188$. http://doi.org/10.1093/applin/amm008

Sevük, T. (2013). The influence of Facebook on interpersonal communication. Eastern Mediterranean University (EMU)-Doğu Akdeniz Üniversitesi (DAÜ).

Timoshchuk, Yu. (2013). Obraz cholovika u masoviy kulturi [Image of man in mass culture]. Hender ta filosofiya. Hender ta kulturolohiya [Gender and philosophy. Gender and culturology], 94-101 [in Ukrainian]

UNFPA Ukraine. (2019). Gender Equality and Response to Domestic Violence in the Private Sector of Ukraine: Call for Action. https://ukraine.unfpa.org/en/BADV2019eng

Facebook. Ukrainians in Germany. https://www.facebook.com/groups/624314044433235

Facebook. Ukrainians in Berlin. https://www.facebook.com/groups/2161546170739893

Facebook. Ukrainians in Munich. https://www.facebook.com/groups/ua.muenchen

Анастасія Кузнєцова. Гендерна відмінність у використанні мови та ставленні до мов у Facebook онлайн-публікаціях українських мігрантів Німеччини. У статті досліджуються гендерні відмінності у використанні мови та мовних ставленнях українських громад Німеччини в онлайнових соціальних мережах. Починаючи з 2014 року, конфлікт на Сході України призвів до надзвичайно інтенсивного потоку українських мігрантів до Західної Європи, що породжує давні проблеми формування ідентичності, використання мови та ставлення до неї як в Україні, так і в межах українських діаспорних спільнот. У цій статті досліджено українську діаспору в Німеччині на предмет мовної ідеології, використання та ставлення до мови шляхом аналізу іiі мовної онлайнактивності. Наш аналіз базується на низці міждисциплінарних методологій, включаючи дослідження позиціонування лінгвістичної ідентичності, гендеру в міграції, уявних мігрантських спільнот та дослідження дискурсивних конструкцій національності, які досліджують мовну індексацію стосовно національної ідентичності. Дані соціальних мереж були зібрані 3 груп Facebook у Німеччині на основі кількості підписників, різноманітності використання мови, частоти публікацій та різноманітності їх соціальної, культурної чи політичної спрямованості. Зазначено, що використання мови членами трьох досліджуваних груп Facebook жодним чином не відображає положення всіх українських іммігрантів у цій країні. Крім того, відсутність доступу до офлайнових мультимодальних і діалогічних мовних взаємодій мігрантів створила обмеження для цього дослідження. Зроблено висновок, що, на відміну від чоловіків, українські жінки-мігрантки, швидше за все, розвиватимуть менш українську орієнтацію ідентичності з меншою увагою до української мови. Тому, якщо національні міфології розглядають жінок як відповідальних за підтримку української мови та традицій, самі жінки, на відміну від українських чоловіків, як правило, використовують міжнародно визнані мови як маркер свого соціального просування. Тому в перспективі в майбутньому використання мови, а також дослідження ідентичності іммігрантів отримають користь від додаткових досліджень, які вивчають більш різноманітні групи іммігрантів.

Ключові слова: гендер; використання мови; ставлення до мов; мовна ідентичність; діаспора. 